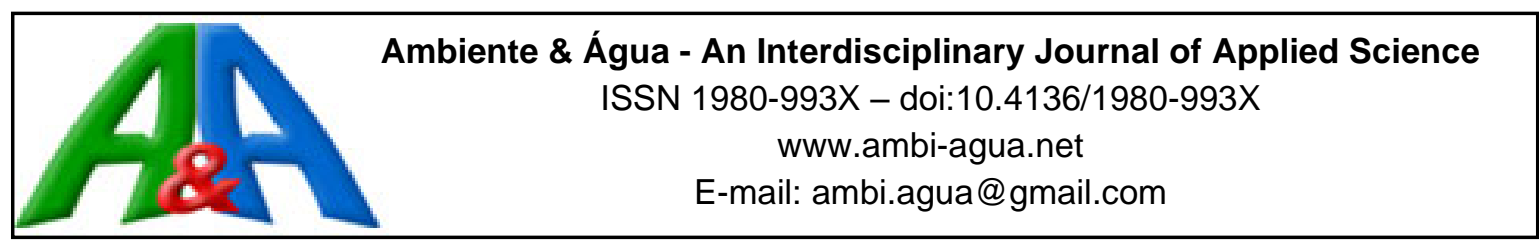

\title{
Evaluation of anaerobic and anoxic reactors installed in serial to treat fish tank effluent
}

\author{
ARTICLES doi:10.4136/ambi-agua.2678
}

Received: 18 Nov. 2020; Accepted: 12 Apr. 2021

\begin{abstract}
Maria Lidia Carra1 ${ }^{1}$; Vitória Teodoro Gonçalves ${ }^{1}$; Tiago Palladino Delforno $^{2}$ iD; Valéria Maia de Oliveira ${ }^{2}$; Ariovaldo José da Silva ${ }^{1 *(D)}$

${ }^{1}$ Faculdade de Engenharia Agrícola. Laboratório de Meio Ambiente e Saneamento. Universidade Estadual de Campinas (UNICAMP), Avenida Cândido Rondon, $n^{\circ}$ 501, Cidade Universitária, CEP: 13083-875,

Campinas, SP, Brazil. E-mail: malidiacarra@gmail.com, vitoriatgoncalves@yahoo.com.br ${ }^{2}$ Centro Pluridisciplinar de Pesquisas Químicas, Biológicas e Agrícolas. Divisão de Recursos Microbianos. Universidade Estadual de Campinas (UNICAMP), Avenida Alexandre Cazellato, n 999, CEP: 13148-218, Paulínia, SP, Brazil. E-mail: tiago.palladino@gmail.com,vmaia@cpqba.unicamp.br

*Corresponding author. E-mail: arijs@unicamp.br
\end{abstract}

\begin{abstract}
Effluent from a fish tank with Nile tilapia (Oreochromis niloticus) was treated in a system of two parallel fixed-bed anaerobic reactors followed by a suspended stirred, anoxic reactor for solids, organic matter and nitrogen removal. Microbial community structure was compared between the reactors and an enriched anammox culture originated from anaerobic sludge by using the PCR (Polymerase Chain Reaction) and DGGE (Denaturing Gradient Gel Electrophoresis) techniques. DGGE analysis revealed three large microbial clusters, namely, the biomass in the inoculum, the biomass growing in the reactors, and the enriched anammox culture. The similarity between the microbial community recovered from the anaerobic reactors and the anammox community was considered low (32.7\%), suggesting differentiation of the bacterial community as a function of the selection of specific anammox groups. The last step in the anoxic reactor had worsened the effluent quality. The potential of organic matter and ammonia removal in a single anaerobic reactor was demonstrated.
\end{abstract}

Keywords: anaerobic reactors, anammox, denitrification, DGGE, nitrification.

\section{Avaliação de reatores anaeróbios e anóxico instalados em série para tratamento de efluentes de tanques de piscicultura}

\section{RESUMO}

Efluentes de um tanque de peixes de cultivo de tilápia do Nilo (Oreochromis niloticus) foram tratados em um sistema de dois reatores anaeróbios de leito fixo paralelos e seguido por um reator agitado suspenso sob ambiente anóxico para remoção de sólidos, matéria orgânica e nitrogênio. A estrutura da comunidade microbiana foi comparada entre os reatores e uma cultura enriquecida de anammox originada de lodo anaeróbio por PCR (Reação em Cadeia de Polimerase) e DGGE (Eletroforese em Gel de Gradiente Desnaturante). A análise de DGGE revelou três grandes aglomerados microbianos, a saber, a biomassa do inóculo, a biomassa nos reatores e a cultura de anammox enriquecida. A similaridade entre a comunidade microbiana recuperada dos reatores anaeróbios e a comunidade anammox foi considerada baixa $(32,7 \%)$,

This is an Open Access article distributed under the terms of the Creative Commons Attribution License, which permits unrestricted use, distribution, and reproduction in any medium, provided the original work is properly cited. 
sugerindo diferenciação da comunidade bacteriana em função da seleção de grupos específicos de anammox. Embora o reator anóxico tenha piorado a qualidade do efluente, os resultados indicam o potencial de remoção de matéria orgânica e amônia em um único reator anaeróbio.

Palavras-chave: anammox, desnitrificação, DGGE, nitrificação, reator anaeróbio.

\section{INTRODUCTION}

Fish production is carried out in intensive and semi-intensive systems by small producers. Fish farming in excavated tanks is largely responsible for semi-intensive and intensive systems, where animals are kept and raised throughout the growing period at high stocking densities (Malpartida Pasco et al., 2018). Animals are fed with high levels of protein that are only partially assimilated, resulting in an excess of this nutrient in the environment (Kaushik and Seiliez, 2010). The main product excreted by aquatic organisms that have been fed with proteins is ammonia. Excessive feeding and excretion contributes to the increase of nitrogen concentration in fish ponds, which can cause toxicity by nitrogen compounds such as ammonia, nitrite and nitrate (Silva et al., 2017). In order to minimize the impacts of nitrogen compounds in fish ponds, producers constantly renew the water without treating the discharged effluent, impacting the receiving rivers. (Coldebella et al., 2017).

The conventional process of nitrogen removal from wastewater is carried out through aerobic nitrification and anaerobic denitrification. In the first aerobic phase, Nitrosomonas spp. oxidize ammonia to nitrite and, in the second phase, Nitrobacter spp. oxidize nitrite to nitrate. Anaerobic denitrifying bacteria reduce nitrate and nitrite to nitrogen gas (Khin and Annachhatre, 2004). These reactions are widely known and have been successfully applied in most wastewater treatment systems (Egli et al., 2001). However, this process has some limitations when the objective is to treat effluents containing high concentrations of nitrogen and low concentration of carbon (low $\mathrm{C} / \mathrm{N}$ ratio) since there are difficulties in the transfer of large amounts of oxygen necessary for nitrification and the need for a large amount of biodegradable organic matter in the denitrification phase (Xing and Clark, 2012). Fish farming effluents are characterized by the high concentration of biochemical oxygen demand (BOD) and the presence of organic and inorganic matter; in this way the efficiency of the process can be impaired and other processes must be explored.

Anammox has become an important subject in the fields of microbiology and environmental engineering because this process has several advantages, including low sludge production, low energy consumption, and no requirement for external organic carbon (Daverey et al., 2015).

The anammox process was investigated in a denitrifying reactor by Mulder et al. (1995). Ammonia $\left(\mathrm{NH}_{4}^{+}\right)$is converted into gaseous nitrogen using nitrite $\left(\mathrm{NO}_{2}{ }^{-}\right)$as an electron acceptor. The anammox process can completely replace the conventional denitrification step of wastewater treatment systems, and save half of the aeration costs in the nitrification phase (Ma et al., 2016).

Anammox bacteria have been detected in several ecosystems. Devol (2003) states that they participate in the nitrogen cycle, and are responsible for 30 to $50 \%$ of the total $\mathrm{N}_{2}$ production of the planet. In addition, they have also been detected in several effluent treatment plants in Germany (Helmer et al., 1999), Switzerland (Egli et al., 2001), England (Schmidt et al., 2003), Belgium (Pynaert et al., 2003), and Australia (Toh and Ashbolt, 2002). The presence of such bacteria in aquatic ecosystems suggests that they are found in any ecosystem that contains nitrogen and has anaerobic zones (Francis et al., 2007).

CANON (Completely Autotrophic Removal of Nitrogen Over Nitrite) is another innovative process. It is the combination of nitrification processes via nitrite and anammox,

Rev. Ambient. Água vol. 16 n. 3, e2678 - Taubaté 2021 
developed in a single reactor aerated by two groups of bacteria (Sliekers et al., 2002). The first group is Nitrosomonas spp., which oxidizes ammonia to nitrite by consuming oxygen and creating anaerobic conditions for the second group, represented by the anaerobic bacteria Planctomycetales, which are responsible for the anammox nitrogen removal process. (Ahn, 2006).

The anammox and CANON processes are considered to be a good alternative for biological nitrogen removal in wastewater treatment (Van Dongen et al., 2001), and can reduce up to 90\% of operating costs (Jetten et al., 2001). In the review study by Nozhevnikova et al. (2012) on the application of the anammox process in the biotechnological treatment of effluents, the authors pointed out a $25 \%$ reduction in aeration costs compared to a complete nitrification process, a $40 \%$ reduction in costs by not adding organic carbon and a reduction of carbon dioxide emissions of $20 \%$.

The anammox process has been used for the treatment and reduction of nitrogen compounds in agricultural environments in recent years, including treatment of anaerobic digestion effluents from food and fruit/vegetable waste, livestock manure, cannery wastewater, and sludge (Dapena-Mora et al., 2006; Fernandes et al., 2018; Kindaichi et al., 2016; Wu et al., 2019; Zhao et al., 2015).

Castine et al. (2012) observed in a settlement pond for the treatment of aquaculture waste the removal of nitrogen compounds and the production of nitrogen gas by denitrification and anammox processes. Other authors have also found the presence of anammox bacteria in fish production systems (Van Duc et al., 2018; Li and Gu, 2016; Tal et al. 2006; Van Kessel et al. 2011; Shen et al. 2016; Lahav et al. 2009) showing the potential for the study and development of technologies for this production system.

According to Dapena-Mora et al. (2006), the anammox bacteria have specific conditions of development and very slow growth, an 11-day period according to Jetten et al. (2001). Therefore, some techniques were developed to obtain anammox biomass.

To have an optimal performance in the anammox process, the effluent must have some specific characteristics, such as low organic load and high ammonia concentration. For the success of the anammox process, it is necessary to have anammox bacteria in the system and to provide the appropriate anaerobic conditions (Nozhevnikova et al., 2012).

Van Duc et al. (2018) enriched anammox bacteria in continuous compacted bed columns with marine sediment from a shrimp pond and had a nitrogen removal efficiency of $88 \%$ at a nitrogen loading rate of $1 \mathrm{~kg} \cdot \mathrm{m}^{-3} \cdot \mathrm{h}^{-1}$. The authors showed that it is possible to obtain an anammox culture from marine sediment and also to reduce nitrogen compounds in an aquaculture treatment system with the anammox process.

Ding et al. (2017) tested three conventional sludges in sequencing batch reactors for Anammox enrichment, including conventional aerobic sludge, denitrification sludge, and anaerobic sludge. The anammox process was completely stabilized in the reactor with denitrifying sludge, obtaining $80 \%$ nitrogen removal in 150 days. Despite the favorable environment for the development of bacteria, the authors observed a fluctuation of nitrogen removal rates throughout the process. Microbiological analysis helped to more easily diagnose what was happening in each reactor.

Mirza et al. (2020) evaluated three different inoculum sources for the anammox process, i.e., anaerobic, aerobic and anoxic sludge from conventional sewage treatment plants. Anaerobic sludge was close to stoichiometric nitrite in ammonia utilization (1.2:1) and resulted in the highest ammonia removal (12.2 $\mathrm{mg} \mathrm{NH}_{4}^{+} \mathrm{g} \mathrm{VS}^{-1}$ day).

Microbial community analysis was carried out by molecular biology tools in treatment systems (Xiao et al., 2009). Genetic fingerprinting of microbial communities provides banding patterns or profiles that reflect the genetic diversity of the community in a given environment. Denaturing gradient gel electrophoresis (DGGE) of PCR amplified gene fragments is one of 
the genetic fingerprinting techniques most widely used in microbial ecology studies on bioreactors (Cabezas et al., 2015). DGGE allows the simultaneous analysis of multiple samples and the comparison of microbial communities based on temporal and spatial differences (Muyzer and Smalla, 1998).

Therefore, it is interesting to look for alternatives and new discoveries for the removal of ammonia, technologies that help fish farmers in managing their production or building an effluent treatment system. It is also important to look for new sources of anammox bacteria and how different groups of bacteria can help remove nutrients and organic matter in a treatment system.

In this study, we evaluated the performance of an anaerobic and anoxic mixed biomass for the treatment of fish waste effluent in anaerobic reactors, and an agitated anoxic reactor for removing organic matter, ammonia, nitrite and nitrate by partial nitrification and the anammox process.

\section{MATERIAL AND METHODS}

\subsection{Treatment System for effluent from fish tank}

Figure 1 shows the scheme of the experimental setup and the sampling points for monitoring. The glass fish tank F, with a volume of $140 \mathrm{~L}$, was supplied with dechlorinated water from tank $\mathrm{W}$, of $250 \mathrm{~L}$ by gravity at a flow rate of $50 \mathrm{~L} \mathrm{~h}^{-1}$ for 90 days and thereafter was reduced to $20 \mathrm{~L} \mathrm{~h}^{-1}$. The higher flow rate was applied for fish adaptation and observation of the treatment system. Nevertheless, the ammonia concentration was not high enough for the selection of anammox bacteria and for this reason the flow rate was decreased to $20 \mathrm{~L} \mathrm{~h}^{-1}$ and maintained throughout the experiment. Therefore, from the 90th day, the flow rate was reduced to $20 \mathrm{~L} \mathrm{~h}^{-1}$ to increase the concentration of ammonia in the treatment system.

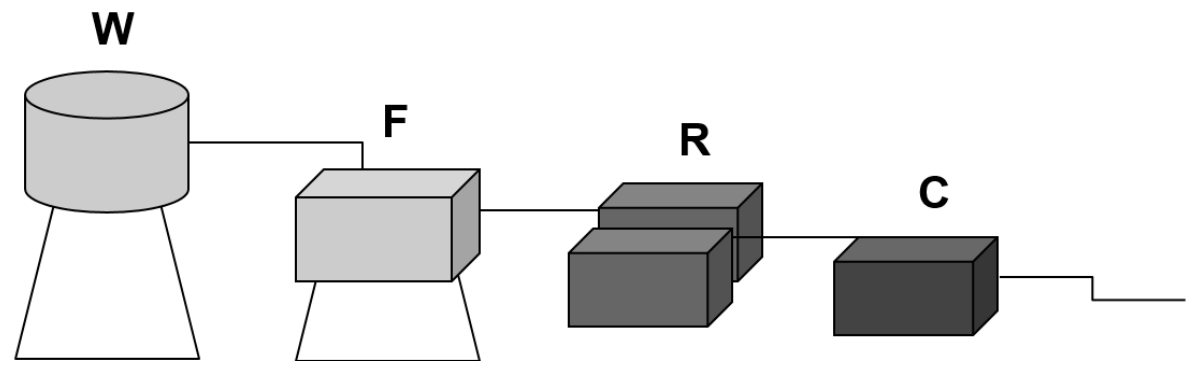

Figure 1. Experimental scheme. W, water supply reservoir; F, fish tank; R, upflow fixed-bed anaerobic reactor; C, suspended stirred reactor.

To simulate the intensive culture, the fish tank was inhabited by juvenile fish Nile's tilapia species (Oreochromis niloticus) with an initial weight of $27 \pm 3 \mathrm{~g}$ and a biomass density of $5 \mathrm{~g}$ $\mathrm{L}^{-1}$. The fish were donated by a Nile tilapia producer from the city of Mogi Mirim, SP, Brazil. The fishes were fed three times a day with a balanced ration containing $30 \%$ crude protein until satiety, limited to $3 \%$ of the average weight of the animals (Kubitza, 2000). Dissolved oxygen (DO) was measured daily to keep the concentration of $3.4 \pm 1.06 \mathrm{mg} \mathrm{L}^{-1}$ by the air compressor Boyu ${ }^{\circledR}$ ACQ-001. The low DO in the fish tank is in order to not compromise the anaerobic activity of the treatment reactors. The tolerance of low DO of tilapia is higher than other farmed fish, some tilapia can tolerate an environment with DO between 2.5-3.0 mg L $\mathrm{m}^{-1}$ for 12 weeks without affecting their growth or mortality (Abdel-Tawwab et al., 2015; Li et al., 2018). A Nile tilapia was chosen for this study because it is a species that adapts to these extreme conditions.

For anaerobic treatment, two parallel upflow fixed-bed anaerobic reactors (FBR) were assembled, made in polypropylene, R (Figure 1) and with volume of $170 \mathrm{~L}$, with dimensions $0.40 \times 0.60 \times 0.74 \mathrm{~m}$ (height $\times$ width $\times$ length) each, containing immobilized biomass from an 
anaerobic baffled reactor sludge (ABRS), treating cattle manure plus dairy barn effluent. Biomass was immobilized in polyurethane foam (Biobob®) randomly disposed upon a steel plate with holes of $2 \mathrm{~cm}$, up to the upper edge of the reactors, at a height of $0.35 \mathrm{~m}$.

Later, the effluent was treated in the stirred reactor, $C$ (Figure 1), also made in polypropylene, and with the same volume and dimensions of the FBR; the biomass grew in suspension, under limited aeration by a submerged pump to enable partial nitrification. This reactor was conceived to operate according to the CANON process, in which nitrite and ammonia should be later removed by anammox biomass in a single reactor (Khin and Annachhatre, 2004).

All the reactors were kept at room temperature; however, they were externally coated with styrofoam plates to minimize the changes of the inside temperature. The treatment system operated for 240 days.

\subsection{Chemical Analysis}

The $\mathrm{pH}$, temperature, dissolved oxygen (DO), turbidity, color, and conductivity of the water were measured daily to ensure the welfare of the animals. Analyses of $\mathrm{pH}$, temperature, conductivity and DO were measured by precision electrodes. Turbidity and color were measured by spectrometry. These analyses were performed according to Standard Methods for Examination of Water and Wastewater (APHA et al., 2005).

During monitoring, samples of supply water $(\mathrm{W})$ and fish tank $(\mathrm{F})$, anaerobic reactors $(\mathrm{R})$ and anoxic reactor effluent (C) (Figure 1), were collected weekly for analyzing chemical oxygen demand (COD), total nitrogen (TN), total carbon (TC), and total solids (TS). Analyses of TN and TC were performed by catalytic oxidation with combustion at $680^{\circ} \mathrm{C}$ in a Shimadzu ${ }^{\circledR}$ brand analyzer, Model TNM-L. The COD measurement was performed by oxidizing organic matter using potassium dichromate as an oxidant in the presence of sulfuric acid and silver ions. The samples were digested in the digester block HACH COD Reactor, and after 2 hours they were read by absorbance on a spectrophotometer HACH DR4000U, according to Standard Method 5220 D (APHA et al., 2005).

For TS, the porcelain capsule was cleaned and dried in a drying oven at a temperature ranging between $103-105^{\circ} \mathrm{C}$ for 1 hour. After cooling to room temperature the capsule was weighed and the value recorded. The sample was well homogenized, taking care to eliminate previously possible interference. One hundred $\mathrm{mL}$ of the sample was measured, and transferred to the porcelain capsule. Again the evaporation process was done, this time using the sample in the oven at $103-105^{\circ} \mathrm{C}$ for 60 minutes. After evaporation, the capsule was taken to the desiccator and allowed to cool. The capsule was then weighed again. The TS value was obtained by the difference in the weighing values. TS analyses were performed according to Standard Methods for Examination of Water and Wastewater (APHA et al., 2005).

\subsection{Statistical Analysis}

All statistical analyses were performed with a 5\% significance. Parametric or nonparametric data were verified by D' Agostino's method (D'Agostino et al., 1990). Hypotheses were tested by ANOVA and Kruskal-Wallis methods (Kruskal, 2007), for parametric and nonparametric data, respectively.

\subsection{Bacterial community analysis}

The similarity between the microbial community growing in the anaerobic and anoxic reactors and an enriched anammox microbial community was assayed by the molecular tool PCR/DGGE. All microbial communities were obtained from the same original inoculum, i.e., ABRS. Anaerobic Sludge is a suitable inoculum for anammox enrichment (Mirza et al. 2020). The enriched anammox culture originated from a parallel study, with the objective of obtaining anammox bacteria, which had the biomass of an ABRS as inoculum, and was selected in a 
sequential batch reactor after $210 \mathrm{~d}$ fed with autotrophic medium according to Dapena-Mora $e t$ al. (2006) (data not shown).

An aliquot from inoculum (I), anammox biomass (E), anaerobic reactor sludge (R), and stirred reactor sludge $(C)$ were centrifuged at 3,000 rpm for 5 minutes until at least $5 \mathrm{~mL}$ of biomass in triplicate.

Total DNA of the microbial community was extracted from each biomass sample $(300 \mu \mathrm{L})$ using PowerSoil DNA Isolation Kit (Mobio), according to manufacturer's instructions. The 16S rRNA gene was partially amplified by PCR reactions using total DNA of the microbial community as a template and the primer pair $341 \mathrm{f}$ (coupled to a clamp with high GC content) and 907r (Muyzer et al., 1993; Muyzer and Smalla, 1998), which are complementary to conserved regions of the $16 \mathrm{~S}$ rRNA gene of Domain Bacteria. PCR reactions were performed at a final volume of $50 \mu \mathrm{L}$ containing 1X PCR buffer (Invitrogen), $1.5 \mathrm{mM} \mathrm{MgCl} 2,0.2 \mu \mathrm{M}$ dNTP Mix (Invitrogen), $0.5 \mu \mathrm{M}$ of each primer, $2.0 \mathrm{U}$ Taq DNA Polymerase (Invitrogen), and $5.0 \mu \mathrm{L}$ of the DNA sample ( $\sim 50 \mathrm{ng})$.

Amplification was carried out on a GeneAmp PCR System 9700 (Applied Biosystems), and the amplification program consisted of 1 denaturation cycle at $94^{\circ} \mathrm{C}$ for $5 \mathrm{~min} ; 35$ cycles at $94^{\circ} \mathrm{C}$ for $1 \mathrm{~min}, 60^{\circ} \mathrm{C}$ for $1 \mathrm{~min}$, and $72^{\circ} \mathrm{C}$ for $2 \mathrm{~min}$, followed by 10 cycles at $60^{\circ} \mathrm{C}$ for 30 seconds and $72^{\circ} \mathrm{C}$ for $1 \mathrm{~min}$. PCR products were first confirmed on $1 \%$ agarose gel stained with $0.02 \mu \mathrm{L} / \mathrm{mL}$ SYBR Safe 10,000X in DMSO (Invitrogen). Amplicons were then subjected to denaturing gradient gel electrophoresis (DGGE) in the Ingeny phor U-2 system (Ingeny International $\mathrm{BV} \circledast$ ), in which $15 \mu \mathrm{L}$ of PCR products were applied to a $6 \%$ polyacrylamide gel at a voltage of $100 \mathrm{~V}$ for 15 hours. The denaturing gradient (urea and formamide) of the gel used for separation of the DNA fragments ranged from $40 \%$ to $65 \%$. After electrophoresis, the gel was stained with $10 \mathrm{~mL}$ of a solution containing $4 \mu \mathrm{L} \mathrm{SYBR}$ Gold (Invitrogen $®$ ) in $1 \mathrm{X}$ TAE buffer for 1 hour in the dark.

DGGE polymorphic band profiles were analyzed by the Bionumerics software (Version 6.6; Applied Maths, Kortrijk, Belgium) after conversion and normalization of the profiles using the bands present in the molecular marker as standard. Band profiles were combined in a single image and analyzed per band, where the bands were automatically selected by the program and visually inspected and corrected, using default parameters and the Dice coefficient. The UPGMA (Unweighted Pair Group Method with Arithmetic Mean) algorithm was used to construct the similarity dendrogram.

\section{RESULTS AND DISCUSSION}

\subsection{Performance of anaerobic and anoxic reactors for removal of organic matter and nitrogen}

Table 1 shows the water quality in the fish tank $(\mathrm{F})$ and in the biological reactors $\mathrm{R}$ and $\mathrm{C}$ (Figure 1). The mean values of temperature, $\mathrm{pH}, \mathrm{DO}$, turbidity, color and electrical conductivity (EC) of the fish tank water were in accordance with the recommended values for the fish species used (Makori et al., 2017).

In Figure 2, we show the content of the pollutants, organic matter, total nitrogen, total carbon, ammonia, nitrite, and nitrate, expressed in volumetric load in the fish tank $(\mathrm{F})$, anaerobic reactors $(\mathrm{R})$ and after the stirred reactor $(\mathrm{C})$.

There was a $20.7 \%$ reduction in turbidity after treatment in the anaerobic reactor due to the retention of solids. The $\mathrm{C}$ reactor reduced an additional $55.4 \%$, resulting in a total reduction of $64.6 \%$. The total solids load was reduced from $179.5 \mathrm{~g} \mathrm{TS} \mathrm{d}^{-1}$ to $127.0 \mathrm{~g} \mathrm{TS} \mathrm{d}^{-1}$ (29.2\% less) (data not shown). Beli et al. (2010) observed a reduced turbidity in $87 \%$ operating an aerobic/anaerobic combined treatment using anaerobic baffled reactor followed by a sand filter. Sánchez et al. (2016) achieved 58.2\% in suspended solid removal with a biofilter using sand as 
support material. In our study, we obtained TS removal of $48 \%$ combining the anaerobic reactor and the stirred reactor. The total removal efficiency showed that the system of anaerobic and aerobic reactors in series was effective in the retention of solids from Nile tilapia production.

Table 1. Quality parameters for water in the fish tank (F), upflow fixed-bed anaerobic reactor $(\mathrm{R})$, suspended stirred reactor $(\mathrm{C})$.

\begin{tabular}{cccc}
\hline & $\mathrm{F}$ & $\mathrm{R}$ & $\mathrm{C}$ \\
\hline Temperature $\left({ }^{\circ} \mathrm{C}\right)$ & $24 \pm 1.8$ & $24 \pm 1.7$ & $24 \pm 1.8$ \\
$\mathrm{pH}$ & $7.27 \pm 0.29$ & $7.25 \pm 0.23$ & $7.30 \pm 0.24$ \\
$\mathrm{DO}\left(\mathrm{mg} \mathrm{O}_{2} \mathrm{~L}^{-1}\right)$ & $3.4 \pm 1.06$ & $0.5 \pm 0.1$ & $0.5 \pm 0.1$ \\
Turbidity $(\mathrm{NTU})$ & $2.32 \pm 2.04$ & $1.84 \pm 0.78$ & $0.82 \pm 0.49$ \\
Color & $32 \pm 46$ & $14 \pm 12$ & $11 \pm 7$ \\
Conductivity $\left(\mu \mathrm{S} \mathrm{cm}^{-1}\right)$ & $340 \pm 76$ & $319 \pm 137$ & $318 \pm 132$ \\
\hline
\end{tabular}

a)

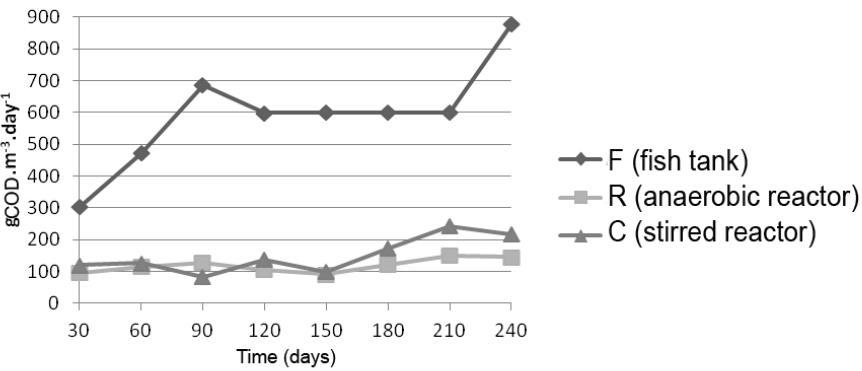

b)
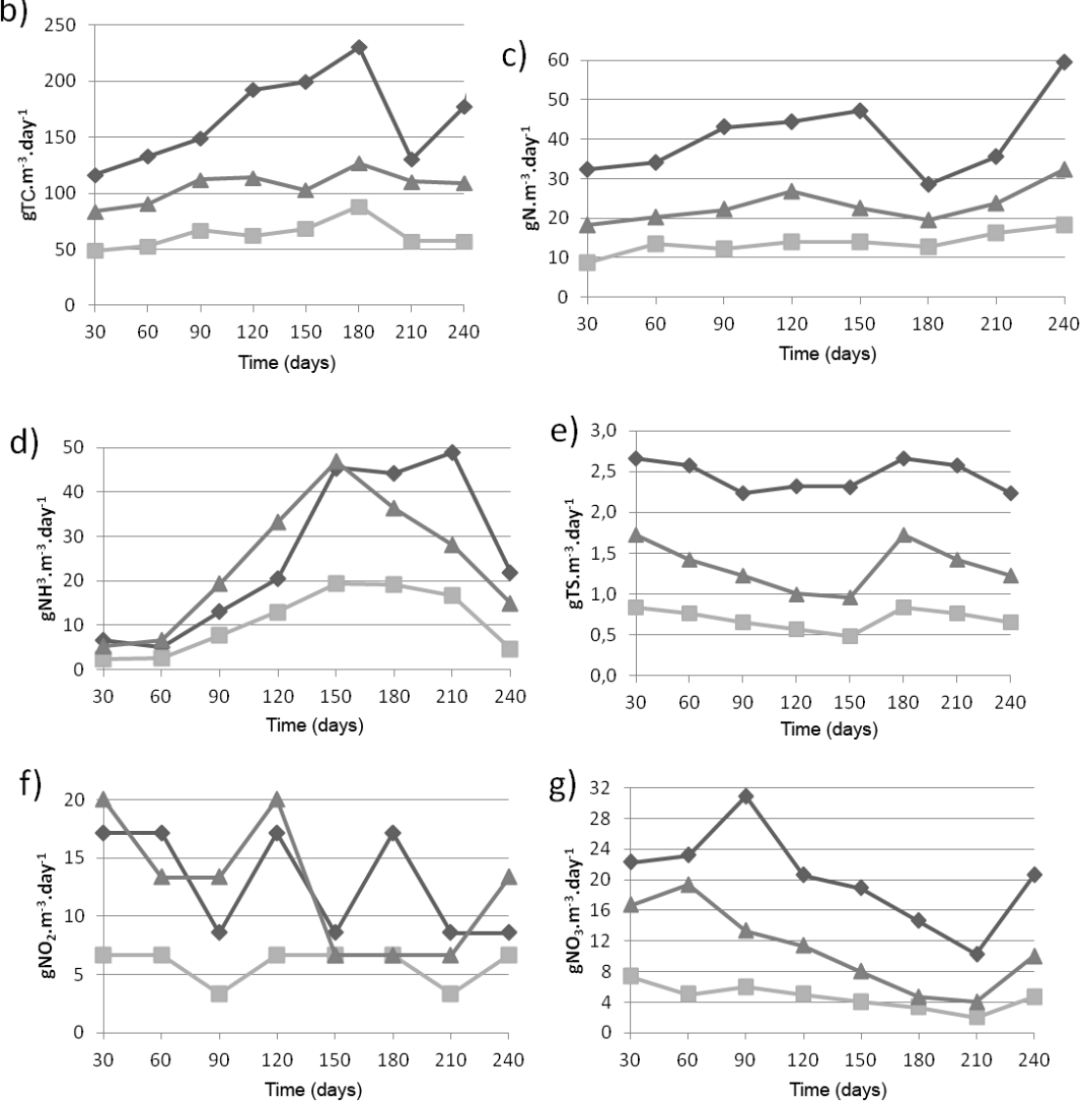

Figure 2. Volumetric loads of COD (a), TC (b), TN (c), Ammonia (d), TS (e), Nitrate (f) and Nitrite (g) in the fish tank (F), anaerobic reactor (R) and after stirred reactor (C) for 240 days.

The DO in the aquarium was $3.2 \mathrm{mg} \mathrm{L}^{-1}$. In the anaerobic reactor, the DO was $0.5 \mathrm{mg} \mathrm{L}^{-1}$. 
The reduction of dissolved oxygen in the anaerobic reactor was due to the low flow and the period of stabilization of the liquid in the anaerobic tank. The low concentration of DO in the reactor $\mathrm{C}$ makes it possible to remove nitrogen by the CANON process. The concentration of organic matter and the $\mathrm{NO}_{2}^{-} / \mathrm{NH}_{3}$ ratio close to 1 also favors the CANON process.

According to Figure 2, carbon and nitrogen (b and c) mean loading rate of the anaerobic reactor was $186.85 \mathrm{~g} \mathrm{~m}^{-3} \mathrm{~d}^{-1}$ and $48.91 \mathrm{~g} \mathrm{~m}^{-3} \mathrm{~d}^{-1}$, i. e., ratio C/N 3.82. The mean carbon and nitrogen load were reduced to $69.90 \mathrm{~g} \mathrm{~m}^{-3} \mathrm{~d}^{-1}(62.59 \%)$ and $15.99 \mathrm{~g} \mathrm{~m}^{-3} \mathrm{~d}^{-1}(67.31 \%)$ in the anaerobic reactors, resulting in a $\mathrm{C} / \mathrm{N}$ ratio of 4.37 for the anoxic reactor. In reactor $\mathrm{C}$, there was an increase in the average carbon and nitrogen load to $55.55 \mathrm{~g} \mathrm{~m}^{-3} \mathrm{~d}^{-1}$ and $10.48 \mathrm{~g} \mathrm{~m}^{-3} \mathrm{~d}^{-3}$, respectively. In reactor R, the volumetric organic load (COD) (a) was reduced from 585.27 to $113.73 \mathrm{~g} \mathrm{~m}^{-3} \mathrm{~d}^{-1}(80.6 \%)$, and in reactor $\mathrm{C}$ it was increased to $149.95 \mathrm{~g} \mathrm{COD} \mathrm{m}^{-3} \mathrm{~d}^{-1}$. This increase was due to biomass growth, since the sample was not filtered before the analysis.

During the first 60 days, the rate of water renewal in the fish tank was higher $\left(50 \mathrm{~L} \mathrm{~h}^{-1}\right.$ for 90 days, and then the flow rate decreased to $20 \mathrm{~L} \mathrm{~h}^{-1}$ ), so the organic load in the anaerobic reactor was lower $\left(388 \pm 120 \mathrm{gCOD} \mathrm{m}^{-3} \mathrm{~d}^{-1}\right)$, increasing to $635 \pm 106 \mathrm{gCOD} \mathrm{m}^{-3} \mathrm{~d}^{-1}$ in the next 240 days due to the reduction of water flow and the consequent increase in the COD concentration in the fish tank and in the reactors. The growth of biomass in the anaerobic reactor was able to remove organic matter, the average COD load was reduced by $80.6 \%$ and the total organic carbon was reduced by $69.0 \%$.

Hussar and Bastos (2008), treating fish effluents with aquatic macrophytes had a COD removal efficiency of $77.7 \%$, considered satisfactory for the system. Correia et al. (2012), evaluated the performance of aerobic fluidized bed reactors with internal circulation in removing carbon through the treatment of different wastewater. When assessing the fish farming effluent, they had 75\% carbon removal. Other authors, such as Davidson et al. (2008), reported the removal of carbon above $60 \%$ in biphasic fluidized bed reactors, with sand as a support and biofilm thickness control for the treatment of fish effluent.

Although the anaerobic reactor $(\mathrm{R})$ is efficient in removing COD, in the stirred reactor $(\mathrm{C})$ the COD load increased by $24.15 \%$, suggesting that the combination of the fixed bed anaerobic reactor and the agitated reactor with suspended biomass was not suitable for removal of organic matter.

The low electrical conductivity measured in average $319 \mu \mathrm{S} \mathrm{cm}^{-1}$ also was a consequence of renewal water. Conductivity is a very important factor for the operation of the Anammox process. Tsai et al. (2019) verified that when the conductivity was between $1250-7500 \mu \mathrm{S} \mathrm{cm}^{-}$ ${ }^{1}$, the total nitrogen removal rate begins to decrease slowly from 64 to $57 \%$, being greatly reduced when the conductivity was higher than $7500 \mu \mathrm{S} \mathrm{cm}^{-1}$, i.e, from 57.1 to $40.9 \%$.

For ammonia, the mean loading rate was reduced from $26.25 \mathrm{~g} \mathrm{~m}^{-3} \mathrm{~d}^{-1}$ to $11.57 \mathrm{~g} \mathrm{~m}^{-3} \mathrm{~d}^{-1}$ $(55.92 \%)$ in reactor $\mathrm{R}$, but it increased in reactor $\mathrm{C}$ to $25.11 \mathrm{~g} \mathrm{~m}^{-3} \mathrm{~d}^{-1}$ (Figure $2 \mathrm{~d}$ ). The mean load of nitrite and nitrate (Figure 2f) was also reduced in the anaerobic reactors, from 12.86 $\mathrm{gNO}_{2}^{-} \mathrm{m}^{-3} \mathrm{~d}^{-1}$ to $5.83 \mathrm{gNO}_{2}^{-} \mathrm{m}^{-3} \mathrm{~d}^{-1}\left(54.66 \%\right.$ ) (Figure 2e), and from $22.29 \mathrm{gNO}_{3}^{-} \mathrm{m}^{-3} \mathrm{~d}^{-1}$ to 7.33 $\mathrm{gNO}_{3}{ }^{-} \mathrm{m}^{-3} \mathrm{~d}^{-1}(67.11 \%)$, respectively. However, it increased in the stirred reactor, resulting in a final effluent load of $12.50 \mathrm{gNO}_{2}^{-} \mathrm{m}^{-3} \mathrm{~d}^{-1}$ and $16.67 \mathrm{gNO}_{3}{ }^{-} \mathrm{m}^{-3} \mathrm{~d}^{-1}$, respectively. The influent $\mathrm{NH}_{3} / \mathrm{NO}_{2}{ }^{-}$ratio at anaerobic reactor decreased from 2.04 to 1.98 in the effluent. In the stirred reactor, this ratio increased to 2.01 , higher than the stoichiometric value for the complete anammox process, i.e., 1.23, thus indicating a lack of nitrite.

In this experiment, the water renewal rate of $20 \mathrm{~L} \mathrm{~h}^{-1}$ maintained a low ammonia concentration, $3.23 \pm 2.08 \mathrm{mg} \mathrm{L}^{-1}$. However, some authors found higher ammonia concentration in fish farming; for instance, Gonzaga et al. (2008) found $10.3 \mathrm{mgNH}_{3} \mathrm{~L}^{-1}$ in Nile 's tilapia tank, and Zamboni-Filho et al. (1997) found concentration above $70 \mathrm{mg} . \mathrm{L}^{-1}$ of ammonia in polyculture tank. 
Despite receiving an effluent with DO concentrations above $3 \mathrm{mg} \mathrm{L}^{-1}$, the DO values in the anaerobic reactor were kept close to zero. In the conventional nitrification process, low concentrations of DO are more restrictive for the growth of nitrite-oxidizing bacteria in comparison with ammonia oxidizing bacteria, which can cause nitrite accumulation in the system (Philips et al., 2002). This explains the partial removal of ammonia and nitrite in the anaerobic reactors. Ding et al. (2017) observed the inhibition of anammox activity and the accumulation of nitrite and nitrate in reactors for enriching anammox bacteria with DO values above $1 \mathrm{mg} \mathrm{L}^{-1}$. Corroborating the study by Jetten et al. (2001), which determines the maximum concentration of $0.2 \mathrm{mgO}_{2} \mathrm{~L}^{-1}$ for the development of anammox activity.

According to Peng and Zhu (2006), low concentrations of DO can cause low rates of nitrification, and they suggest DO concentration between 1.0 and $1.5 \mathrm{mg} \mathrm{L}^{-1}$ for nitrification. Here, the DO concentration was maintained below $1 \mathrm{mg} \mathrm{L}^{-1}$ in order to produce nitrite for the anammox process, according to a stoichiometric $\mathrm{NH}_{4}^{+} / \mathrm{NO}_{2}{ }^{-}$ratio close to 1.31 , as shown in Equation 1 (Khin and Annachhatre, 2004). In Equation 1, the last factor represents the biomass.

$$
\mathrm{NH}_{4}{ }^{+}+1.31 \mathrm{NO}_{2}{ }^{-}+0.0425 \mathrm{CO}_{2} \rightarrow 1.045 \mathrm{~N}_{2}+0.22 \mathrm{NO}_{3}{ }^{-}+1.87 \mathrm{H}_{2} \mathrm{O}+0.090 \mathrm{H}^{-}+0.0425 \mathrm{CH}_{2} \mathrm{O}
$$

The values of the $\mathrm{NH}_{4}{ }^{+} / \mathrm{NO}_{2}{ }^{-}$ratio in the system effluent were found above the theoretical value for the anammox process, i.e., close to 1 , indicating a lack of nitrite. We may infer that the $\mathrm{NH}_{4}{ }^{+} / \mathrm{NO}_{2}{ }^{-}$ratio in the anaerobic and anoxic reactors did not present the best ratio for anammox, indicating that partial nitrification in both reactors had ended.

Because the stoichiometric ratio for the anammox process $\mathrm{NH}_{3} / \mathrm{NO}_{2}{ }^{-}$is 1.23 , and this value is lower than values verified in the influent and effluent of the anaerobic and anoxic reactors, 2.04 and 1.98, ammonia and nitrite were partially removed in 56\% and 55\%, respectively.

Unfortunately, in this experiment, the effluent quality worsened after being treated in the anoxic reactor, and ammonia and nitrite concentrations increased, suggesting that a suspended anoxic reactor can be used to supply an anaerobic FBR with nitrite, and improve the efficiency in the latter and not as a final unity.

Therefore, ammonia and nitrite removal should occur in a single reactor. In fact, Xiao et al. (2009) confirmed the coexistence of nitrifiers, denitrifiers, and anammox bacteria in a single batch sequencing reactor by using PCR-DGGE, and justified that ammonia removal occurred due to the growth of aerobic bacteria in the surface and anaerobic bacteria inside the biofilm. According to the authors, aerobic bacteria supply nitrite to anammox bacteria. These data corroborate the fact that in this study we found nitrite and nitrate in the reactors, indicating the coexistence of nitrification and anammox reactions.

The low efficiency in the anoxic reactor concerning ammonia and nitrite removal could be explained by the presence of dissolved oxygen. The average DO concentration was $0.5 \mathrm{mg} \mathrm{L}^{-1}$, considering that the anammox process takes place under anoxic conditions, and low concentrations of oxygen in the medium may already interfere with the efficiency of the process. Strous et al. (1997) demonstrated that the activity of the anammox bacteria undergoes a temporary inhibition if the DO concentration is up to $0.2 \mathrm{mg} \mathrm{L}^{-1}$, and this inhibition can be reversed under anoxic conditions. At DO concentrations between 0.2-1.0 $\mathrm{mg} \mathrm{L}^{-1}$, the bacteria undergo complete inhibition (Strous et al., 1997).

\subsection{Bacterial community}

The 16S rDNA fragments were successfully amplified from the community DNA obtained from the sludge samples (data not shown). Dendrograms generated from the DGGE band profiles by DICE correlation coefficients are shown in Figure 3. 


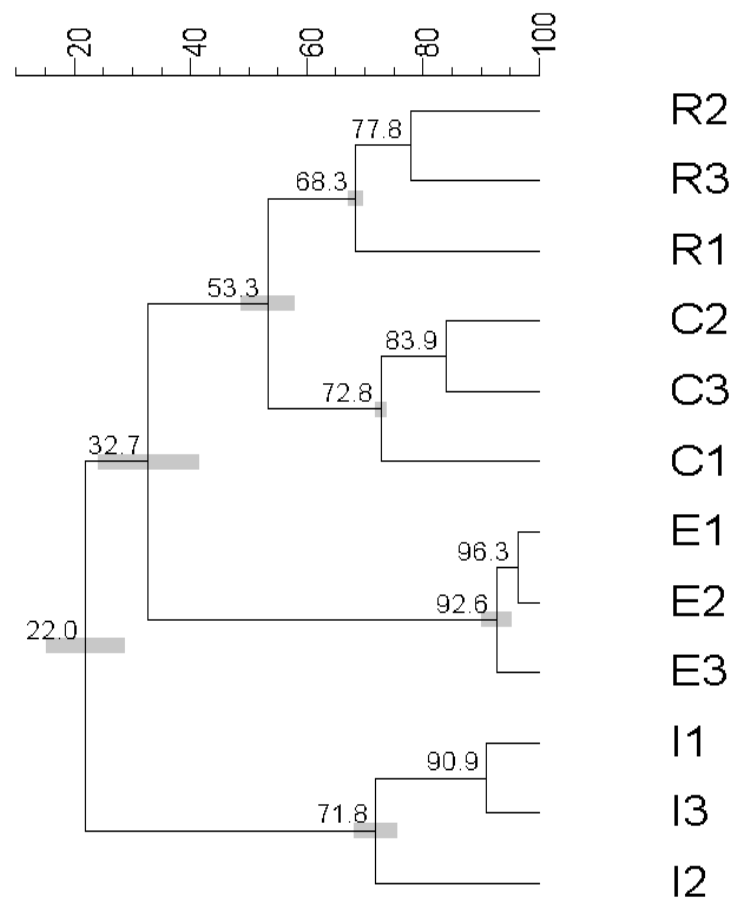

Figure 3. Dendrogram of similarity based on the DGGE band profiles of the samples, obtained using the DICE coefficient and the UPGMA algorithm (BioNumerics program $\mathrm{v}$. 6.6). I1, I2, and I3 correspond to inoculum samples; E1, E2 and E3, to anammox biomass; $\mathrm{R} 1, \mathrm{R} 2$ and $\mathrm{R} 3$, to samples from the anaerobic reactor; and $\mathrm{C} 1, \mathrm{C} 2$, and $\mathrm{C} 3$, to samples from the stirred reactor. Values in each node represent the percentage of similarity, and the bar is the standard deviation.

Three distinct bacterial clusters were recovered based on the similarity dendrogram, which corresponded to the different groups of samples analyzed. The first cluster, R, contains microorganisms developed in the anaerobic reactor; the second cluster, $\mathrm{C}$, refers to microorganisms developed in the anoxic reactor. These two clusters were more similar $(53.3 \%)$ among each other in comparison to the others. Cluster E, which corresponds to the enriched anammox biomass, showed $32.7 \%$ similarity with clusters $\mathrm{R}$ and $\mathrm{C}$; whereas cluster I, which corresponds to the inoculum used for the enrichment and starting of the reactors, was the most distinct (22\% similarity with the others).

Cultivation-independent analysis by DGGE allowed us to evaluate and compare the complexity of the bacterial community present in the inoculum (I), enriched anammox biomass $(\mathrm{E})$, and biomass from reactors $(\mathrm{R})$ and $(\mathrm{C})$. The dendrogram showed the formation of three large groups, the biomass growing in anaerobic and anoxic reactors, the enrichment biomass anammox, and the inoculum.

The level of similarity observed between the R group and $\mathrm{C}$ group was $53.3 \%$ for the DICE coefficient. The anaerobic reactor (group R) and the anoxic reactor (group C) were operated in series, in such a way that the microorganisms developed in the anaerobic reactor were probably taken to the anoxic reactor by the effluent. The level of similarity in the $\mathrm{R}$ and $\mathrm{C}$ reactors was not higher because different processes of nutrient removal occurred in the reactors, which influenced the microbial community developed in each one.

Replicates were consistent and more similar to each other than between the samples. 
Bacterial communities of $\mathrm{R}$ and $\mathrm{C}$ reactors were more similar $(53.3 \%$ in the case of the DICE coefficient) when compared with inoculum and enrichment samples. These reactors were operated in the same conditions of dissolved oxygen, $0.5 \mathrm{mg} \mathrm{L}^{-1}$, and both showed nitrification and denitrification activity.

The low similarity between the band profiles of the reactor biomass (Groups R and C) in relation to the inoculum (Group I) may suggest that operating conditions and the characteristics of the substrate possibly enabled the selection of specific bacterial populations that were in low abundance in the inoculum.

Biomass from reactors also demonstrated some similarity with the anammox biomass, $32.7 \%$ as determined by DICE coefficients. The consumption of nitrite and ammonia in the $\mathrm{R}$ reactor and the production of nitrate in the $\mathrm{C}$ reactor suggest that anammox activity took place in both reactors.

Authors of recent studies have indicated the presence of anammox bacteria in sediments of fish culture tanks (van Kessel et al., 2011; Lahav et al., 2009; Tal et al., 2006). The origin of these bacteria would be the feces of the animals, and some aquatic animals possess bacteria of the phylum Planctomycetes in their intestines (Fuerst, 2004). Some similarities observed between fish tank treatment and enriched anammox bacteria can be explained both by the origin of the inoculum and the possible development of anammox bacteria in fish feces.

\section{CONCLUSIONS}

- The rate of water renewal used in this experiment resulted in a low concentration of ammonia, total nitrogen, nitrite and nitrate compared to values reported in the literature, and the assay was ineffective for removing ammonia and nitrite;

- The anaerobic reactor was effective in the removal of COD, ammonia, nitrite, and nitrate probably due to the anammox and simultaneous denitrification;

- The increase in the load of organic matter, ammonia, nitrate and nitrite in the stirred reactor showed that this configuration of the reactor after the anaerobic reactor was not viable for the CANON process;

- The presence of oxygen in the stirred reactor may have caused the removal of ammonia by the partial nitrification process. However, further studies must be carried out to prove the system as a nitrite supplier for an anaerobic reactor for the removal of ammonia by anammox process;

- There was some similarity in the microbial community of the reactors and the anammox community. However, the biggest similarity was observed among the anaerobic and anoxic reactors.

\section{ACKNOWLEDGMENTS}

The authors are grateful to the Environmental Control Laboratory of the School of Agriculture Engineering, University of Campinas, for the space to experimental installation, to the Bioproj Environment Technology, for donation of support material, Piscicultura Pollettini, for donation of fish and to Capes Foundation from the Brazilian Ministry of Education, for the scholarship, and to the National Council of Scientific and Technological Development - CNPq, for the financial support process no. 481361/2013-8, and to Espaço da Escrita - Pró-Reitoria de Pesquisa - UNICAMP - for the language services provided.

\section{REFERENCES}

AHN, Y. H. Sustainable nitrogen elimination biotechnologies: A review. Process $\begin{array}{llllll}\text { Biochemistry. } & \text { v. } & 41, & \text { n. } & 8, & \text { p.1709-1721, }\end{array}$ https://dx.doi.org/10.1016/j.procbio.2006.03.033 
ABDEL-TAWWAB, M.; HAGRAS, A. E.; ELBAGHDADY, H. A. M. Effects of dissolved oxygen and fish size on Nile tilapia, Oreochromis niloticus (L.): growth performance, whole-body composition, and innate immunity. Aquaculture, v. 23, p. 1261-1274, 2015. https://doi.org/10.1007/s10499-015-9882-y

APHA; AWWA; WEF. Standard Methods for the Examination of Water and Wastewater. 21. ed. Washington, 2005.

BELI, E.; HUSSAR, G. J.; HUSSAR, D. H. Redução de DQO e Turbidez de efluente de uma unidade suinícultura empregando reator anaeróbio compartimentado (RAC) seguido de filtro biológico e filtro de areia. Engenharia Ambiental, v. 7, n. 1, p. 5-19, 2010.

CASTINE, S. A.; ERLER, D. V.; TROTT, L. A.; PAUl, N. A.; NYS, R.; EYRE, B. D. Denitrification and anammox in tropical aquaculture settlement ponds: an isotope tracer approach for evaluating N2 production. PLos ONE, v. 7, n.9, 2012. https://doi.org/10.1371/journal.pone.0042810

CABEZAS, A.; de ARAUJO, J. C.; CALLEJAS, C.; GALÈS, A.; HAMELIN, J.; MARONE, A.; SOUZA, D. Z.; TRABLY, E.; ETCHEBEHERE, C. How to use molecular biology tools for the study of the anaerobic digestion process? Reviews in Environmental Science Biotechnology, v. 14, n.4, p. 555-593, 2015. https://dx.doi.org/10.1007/s11157015-9380-8

COLDEBELlA, A.; GENTELINI, A. L.; PIANA, P. A.; COLDEBELLA, P. F.; BOSCOLO, W. R.; FEIDEN, A. Effluents from fish farming ponds: A view from the perspective of its main components. Sustainability. v. 10, n.1, p.1-16, 2017. https://dx.doi.org/10.3390/su10010003

CORREIA, G. T.; ANDRÉS, I.; ORTIZ, S.; GEBARA, D.; SOBRINHO, M. D.; MATSUMOTO, T. Desempenho de Reatores Aeróbios de Leito Fluidizado com Circulação interna na remoção de matéria carbonácea tratando diferentes águas residuárias. Interciência, v. 37, n. 4, p. 266-271, 2012.

D’Agostino, R. B.; BELANGER, A.; D’AGOstino Jr., R. B. A Suggestion for Using Powerful and Informative Tests of Normality. The American Statistician, v. 44, p. 316321, 1990. https://doi.org/10.2307/2684359

DAPENA-MORA, A.; CAMPOS, J. L.; MOSQUERA-CORRAL, A.; MÈNDEZ, R. Anammox process for nitrogen removal from anaerobically digested fish canning effluents. Water $\begin{array}{lllllll}\text { Science } & \text { Technology. } & \text { v. 53, } & \text { n. 12, po6 }\end{array}$ https://dx.doi.org/10.2166/wst.2006.429

DAVEREY, A.; CHEI, P. C.; DUTTA, K.; LIN, J. G. Statistical analysis to evaluate the effects of temperature and $\mathrm{pH}$ on anammox activity. International Biodeterioration and Biodegradation, n. 102, p. 89-93, 2015. https://dx.doi.org/10.1016/j.ibiod.2015.03.006

DAVIDSON, J.; HELWIG, N.; SUMMERFELT, S.T. Fluidized sand biofilters used to remove ammonia, biochemical oxygen demand, total coliform bacteria, and suspended solids from an intensive aquaculture effluent. Aquacultural Engineering, v. 39, n. 1, p. 6-15, 2008. https://dx.doi.org/10.1016/j.aquaeng.2008.04.002

DEVOL, A. H. Solution to a marine mystery. Nature, v. 422, p. 575-576, 2003. https://dx.doi.org/doi.org/10.1038/422575a 
DING, Z.; VENTORINO, V.; PANICO, A.; PEPE, O.; VAN HULLEBUSCH, E.D.; PIROZZI, F.; BOURVEN, I.; GUIBAUD, G.; ESPOSITO, G. Enrichment of Anammox Biomass from Different Seeding Sludge: Process Strategy and Microbial Diversity. Water, Air and Soil Pollution, v. 228, n. 1, p. 1-13, 2017. https://dx.doi.org/10.1007/s11270-016$3181-8$

EGLI, K.; FANGER, U.; ALVAREZ, P. J. J.; SIEGRIST, H.; VAN DER MEER, J. R.; ZEHNDER, A. J. B. Enrichment and characterization of an anammox bacterium from a rotating biological contactor treating ammonium-rich leachate. Archives of Microbiology, v. 175, n. 3, p. 198-207, 2001. https://dx.doi.org/10.1007/s002030100255

FERNANDES, L.A.; PEREIRA, A. D.; LEAL, C. D.; DAVENPORT, R.; WERNER, D.; MOTA FILHO, C. R.; BRESSANI-RIBEIRO, T.; LEMOS CHERNICHARO, C. A.; ARAÚJO, J. C. Effect of temperature on microbial diversity and nitrogen removal performance of an anammox reactor treating anaerobically pretreated municipal $\begin{array}{llllll}\text { wastewater. Bioresource Technology., v. 258, p. 208-219, } 2018 . & \end{array}$ https://doi.org/10.1016/j.biortech.2018.02.083

FRANCIS, C. A.; BEMAN, J. M.; KUYPERS, M. M. M. New processes and players in the nitrogen cycle: The microbial ecology of anaerobic and archaeal ammonia oxidation. ISME Journal, v. 1, n. 1, p.19-27, 2007. https://dx.doi.org/10.1038/ismej.2007.8

FUERST, J. A. Planctomycetes - a phylum of emerging interest for microbial evolution and ecology. World Federation for Culture Collections Newsletter, v. 38, p.1-11, 2004.

GONZAGA, G.; ANTONIO, H.; MONTEIRO, F. Impacto das Atividades de Aqüicultura e Sistemas de Tratamento de Efluentes com Macrófitas Aquáticas - Relato de Caso. Boletim do Instituto de Pesca, v. 34, p.163-173, 2008. http://orcid.org/0000-0003$3565-6838$

HELMER, C.; KUNST, S.; JURETSCHKO, S.; SCHMID, M. C.; SCHLEIFER, K. H.; WAGNER, M. Nitrogen Loss in a Nitrifying Biofilm System. Water Science and Technology, v. 39, p.13-21, 1999. https://doi.org/10.1016/S0273-1223(99)00145-6

HUSSAR, G. J.; BASTOS, M. C. Tratamento de efluente de piscicultura com macrófitas aquáticas flutuantes. Engenharia Ambiental, v. 5, n. 3, p. 274-285, 2008.

JETTEN, M. S. M.; WAGNER, M.; FUERST, J.; VAN LOOSDRECHT, M. C. M.; KUENEN, J. G.; STROUS, M. Microbiology and application of the anaerobic ammonium oxidation ('anammox') process. Environmental Biotechnology, v. 12, p. 283-288, 2001. https://dx.doi.org/10.1016/S0958-1669(00)00211-1

KAUSHIK, S. J.; SEILIEZ, I. Protein and amino acid nutrition and metabolism in fish: current knowledge and future needs. Aquaculture Research, v. 41, n. 3, p. 322-332, 2010. https://dx.doi.org/10.1111/j.1365-2109.2009.02174.x

KINDAICHI, T.; AWATA, T.; MUGIMOTO, Y.; RATHNAYAKE, R. M. L. D.; KASAHARA, S.; SATOH, H. Effects of organic matter in livestock manure digester liquid on microbial community structure and in situ activity of anammox granules. $\begin{array}{lllll}\text { Chemosphere. } & \text { v. } & 159, & \text { p. } & 300-307,\end{array}$ https://doi.org/10.1016/j.chemosphere.2016.06.018

KHIN, T.; ANNACHHATRE, A. P. Novel microbial nitrogen removal processes.

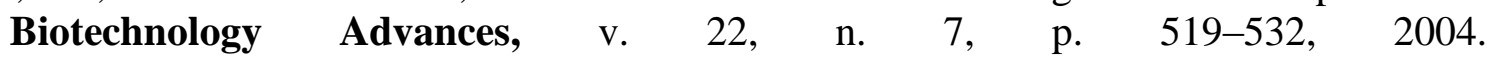
https://dx.doi.org/10.1016/j.biotechadv.2004.04.003 
KRUSKAL, W. H. A Nonparametric test for the Several Sample Problem. The Annals of $\begin{array}{llllll}\text { Mathematical Statistics, } & \text { v. } & 23, & \text { p. } & \text { 525-540, }\end{array}$ https://dx.doi.org/10.1214/aoms/1177729332

KUBITZA, F. Tilápias. Panorama da Aquicultura, v. 10, n. 59, p. 44-53, 2000. https://dx.doi.org/10.3109/14764172.2011.552607

LAHAV, O.; MASSADA, I.B.; YACKOUBOV, D.; ZELIKSON, R.; MOZES, N.; TAL, Y.; TARRE, S. Quantification of anammox activity in a denitrification reactor for a recirculating aquaculture system. Aquaculture, v. 288, n. 1-2, p. 76-82, 2009. https://dx.doi.org/10.1016/j.aquaculture.2008.11.020

LI, M.; XIAODAN, W.; CHANGLE, Q.; ERCHAO, L.; ZHENYU, D.; JIAN, G.Q.; LIQIAO, C. Metabolic response of Nile tilapia (Oreochromis niloticus) to acute and chronic $\begin{array}{lllllll}\text { hypoxia stress. Aquaculture, v. 495, p. 187-195, } 2018 . & \text {. }\end{array}$ https://dx.doi.org/10.1016/j.aquaculture.2018.05.031

LI, M; GU, J. The diversity and distribution of anammox bacteria in the marine aquaculture zones. Applied Microbiology and Biotechnology, v. 100, n. 20, p. 8943-8953, 2016. https://doi.org/10.1007/s00253-016-7690-6

MA, B.; WANG, S.; CAO, S.; MIAO, Y.; JIA, F.; DU, R.; PENG, Y. Biological nitrogen removal from sewage via Anammox: Recent advances. Bioresource Technology, v. 200, p. 981-990, 2016. https://doi.org/10.1016/j.biortech.2015.10.074

MAKORI, A. J.; ABUOM, P. O.; KAPIYO, R.; ANYONA, D. N.; DIDA, G. O. Effects of water physico-chemical parameters on tilapia (Oreochromis niloticus) growth in earthen ponds in Teso North Sub-County, Busia County. Fisheries and Aquatic Sciences, v. 20, n. 1, p. 1-10, 2017. https://dx.doi.org/10.1186/s41240-017-0075-7

MALPARTIDA PASCO, J. J.; CARVALHO FILHO, J. W.; de ESPIRITO SANTO, C. M.; VINATEA, L. Production of Nile tilapia Oreochromis niloticus grown in BFT using two aeration systems. Aquaculture Research, v. 49, n. 1, p. 222-231, 2018. https://dx.doi.org/10.1111/are.13451

MULDER, A. A.; VAN DE GRAFF, L. A.; ROBERTSON, J. G. K. Anaerobic Ammonium Oxidation Discovered in a denitrifying fluidized bed reactor. FEMS Microbiology Ecology, v. 16, n. 3, p. 177-184, 1995. https://doi.org/10.1111/j.15746941.1995.tb00281.x

MIRZA, M. W.; D’SILVA, T.; GANI, M. K.; AFSAR, S. S.; GAUR, R. Z.; MUTIYAR, P. K.; KHAN, A. A.; DIAMANTIS, V.; LEW, B. Cultivation of anaerobic ammonium oxidizing bacteria (AnAOB) using different sewage sludge inoculums: process performance and microbial community analysis. Journal of Chemical Technology and Biotechnology, v. 96, n. 2, p. 454-464, 2020. https://doi.org/10.1002/jctb.6560

MUYZER, G.; SMALLA, K. Application of denaturing gradient gel electrophoresis (DGGE) and temperature gradient gel electrophoresis (TGGE) in microbial ecology. Antonie Van Leeuwenhoek, v. 73, p. 127-141, 1998. https://doi.org/10.1023/A:1000669317571

MUYZER, G., WAAL, E. C. D. E.; UITTERLINDEN, A. G. Profiling of Complex Microbial Populations by Denaturing Gradient Gel Electrophoresis Analysis of Polymerase Chain Reaction-Amplified Genes Coding for 16S rRNA. Applied and Environmental Microbiology, v. 59, n. 3, p. 695-700, 1993. 
NOZHEVNIKOVA, A.N.; SIMANKOVA, M. V.; LITTI, Y. V. Application of the microbial process of anaerobic ammonium oxidation (ANAMMOX) in biotechnological wastewater treatment. Applied Biochemistry and Microbiology, v. 48, n. 8, p. 667-684, 2012. https://dx.doi.org/10.1134/s0003683812080042

PENG, Y., ZHU, G. Biological nitrogen removal with nitrification and denitrification via nitrite pathway. Applied Microbiology and Biotechnology, v. 73, n. 1, p. 15-26, 2006. https://dx.doi.org/10.1007/s00253-006-0534-z

PHILIPS, S.; LAANBROEK, H. J.; VERSTRAETE, W. Origin, causes and effects of increased nitrite concentrations in aquatic environments. Reviews in Environmental Science and Bio/Technology, v. 1, p. 115-141, 2002. https://dx.doi.org/10.1023/A:1020892826575

PYNAERT, K.; SMETS, B. F.; WYFFELS, S.; BEHEYDT, D.; SICILIANO, S.D.; VERSTRAETE, W. Characterization of an autotrophic nitrogen-removing biofilm from a highly loaded lab-scale rotating biological contactor. Applied and Environmental $\begin{array}{lllllll}\text { Microbiology, } & \text { v. } 69, \quad \text { n. } & 6, \quad \text { p. } & \text { 3626-3635, }\end{array}$ https://dx.doi.org/10.1128/AEM.69.6.3626-3635.2003

SÁNCHEZ, O. I.; DOLLY REVELO, R.; ÁLVARO BURBANO, M.; ROBERTO GARCÍA, C.; CAMILO GUERRERO, R.; DIANA BELTRÁN, T.; LUIS BENAVIDES, M. Performance of different biofilters in a recirculating system for rainbow trout farming. Revista MVZ Cordoba, v. 21, n. 2, p. 5426-5440, 2016. https://doi.org/10.21897/rmvz.608

SCHMIDT, I.; SLIEKERS, O.; SCHMID, M.; BOCK, E.; FUERST, J.; KUENEN, J.G.; JETTEN, M. S. M.; STROUS, M. New concepts of microbial treatment processes for the nitrogen removal in wastewater. FEMS Microbiology Reviews. v. 27, n. 4, p.481-492, 2003. https://dx.doi.org/10.1016/S0168-6445(03)00039-1

SHEN, L.; WU, H.; GAO, Z. Q.; RUAN Y. J.; XU, X. H.; LI, J.; MA, S. J.; ZHENG, P. H. Evidence for anaerobic ammonium oxidation process in freshwater sediments of aquaculture ponds. Environmental Science and Pollution Research, v. 23, n. 2, p. 1344-1352. 2016.

SILVA, L.; ESCALANTE, E.; VALDÉS-LOZANO, D.; HERNÁNDEZ, M; GASCALEYVA, E. Evaluation of a semi-intensive aquaponics system, with and without bacterial biofilter in a tropical location. Sustainability, v. 9, n. 4, p. 592, 2017. https://dx.doi.org/10.3390/su9040592

SLIEKERS, A. O. et al. Completely autotrophic nitrogen removal over nitrite in one single reactor. Water research, v. 36, n. 10, p. 2475-2482, 2002. https://doi.org/10.1016/S0043-1354(01)00476-6

STROUS, M.; VAN GERVEN, E.; KUENEN, J.G.; JETTEN, M. Effects of aerobic and microaerobic conditions on anaerobic ammonium- oxidizing (anammox) sludge. Applied and Environmental Microbiology, v. 63, n. 6, p. 2446-2448, 1997.

TAL, Y; WATTS, J.; SCHREIER, H. Anaerobic ammonium-oxidizing (anammox) bacteria and associated activity in fixed-film biofilters of a marine recirculating aquaculture system. Applied and Environmental Microbiology, v. 72, n. 4, p. 2896-2904, 2006. https:/dx.doi.org/10.1128/AEM.72.4.2896-2904.2006

TOH, S.; ASHBOLT, N. Adaptation of anaerobic ammonium-oxidising consortium to synthetic coke-ovens wastewater. Applied Microbiology and Biotechnology. v. 59, n.2-3, p.344352, 2002. https://dx.doi.org/10.1007/s00253-002-1007-7 
TSAI, T-Y.; LO, H-S.; CHUANG, H-P.; JI, Y-LYANG, M.; JOU C-J. Effects of conductivity in wastewater for the anaerobic ammonium oxidation (anammox) process. Journal of Environmental Protection and Ecology, v. 20, n. 4, p. 1904-1911, 2019.

VAN DONGEN, U.; JETTEN, M. S. M.; LOOSDRECHT, M. C. M. Sharon-anammox process for the treatment of ammonium rich wastewater. Water Science \& Technology, v. 44, p.153-160, 2001. https://doi.org/10.2166/wst.2001.0037

VAN DUC, L.; SONG, B.; ITO, H.; HAMA, T.; OTANI, M.; KAWAGOSHI, Y. High growth potential and nitrogen removal performance of marine anammox bacteria in shrimpaquaculture sediment. Chemosphere. v. 196, p. 69-77, 2018. https://dx.doi.org/10.1016/j.chemosphere.2017.12.159

VAN KESSEL, M.A.H.J.; HARHANGI, H.R.; FLIK, G., JETTEN, M.S.M.; KLAREN, P.H.M.; OP DEN CAMP, H.J.M. Anammox bacteria in different compartments of recirculating aquaculture systems. Biochemical Society Transactions, v. 39, n. 6, p. 1817-1821, 2011. https://dx.doi.org/10.1042/BST20110743

XIAO, Y.; ZENG, G. M.; YANG, Z. H.; LIU, Y. S.; MA, Y. H.; YANG, L.; WANG, R. J.; $\mathrm{XU}, \mathrm{Z}$. Y. Coexistence of nitrifiers, denitrifiers and Anammox bacteria in a sequencing batch biofilm reactor as revealed by PCR-DGGE. J Journal of Applied Microbiology, v. 106, n. 2, p. 496-505, 2009. https://dx.doi.org/10.1111/j.1365-2672.2008.04017.x

XING, Y.; CLARK, I. Anaerobic Ammonium Oxidation in Waste Water -An Isotope Hydrological Perspective. In: EINSCHLAG, F. S. G. (ed.). Waste Water: treatment reutilization. Rijeka: InTech, 2012. https://dx.doi.org/10.5772/16154

WU, L.; SHEN, M.; LI, J.; HUANG, S.; LI, Z.; YAN, Z.; PENG, Y. Cooperation between partial-nitrification, complete ammonia oxidation (comammox), and anaerobic ammonia oxidation (anammox) in sludge digestion liquid for nitrogen removal. Environmental Pollution, v. 254, p. 112965, 2019. https://dx.doi.org/10.1016/j.envpol.2019.112965

ZAMBONI-FILHO, E.; BARBOSA, N. D.; GONÇALVES, S. M. Caracterização e tratamento do efluente das estações de Piscicultura. Revista Unimar, v. 19, p. 537-548, 1997.

ZHAO, J.; ZUO, J.; LIN, J.; LI, P. The performance of a combined nitritation-anammox reactor treating anaerobic digestion supernatant under various $\mathrm{C} / \mathrm{N}$ ratios. Journal of $\begin{array}{llllll}\text { Environmental } & \text { Science, } & \text { v. } & 3015 .\end{array}$ https://dx.doi.org/10.1016/j.jes.2014.08.022 